Sains Malaysiana 51(1)(2022): 261-269

http://doi.org/10.17576/jsm-2022-5101-21

\title{
Distribution Serovar and Risk Factors on the Incidence of Canine Leptospirosis after Flood in Jakarta, Indonesia
}

(Taburan Serovar dan Faktor Risiko terhadap Kejadian Leptospirosis Anjing Selepas Banjir di Jakarta, Indonesia)

\author{
Ambar Retnowati, Agustin Indrawati*, Upik KeSumawati Hadi, SAFiKa \& SusAn M Noor
}

\begin{abstract}
Leptospirosis is a zoonosis, which has become a serious problem, especially in areas with high rainfall. Massive leptospirosis occurs after heavy rains or floods. This study aims to analyze the types and distribution of leptospira bacteria serovars and risk factors for leptospirosis in post-flood dogs. The research was conducted from January to March 2020 at the Ragunan Animal Hospital and independent clinics in Jakarta, Bekasi, Depok and South Tangerang. This study used a cross-sectional study of serum samples from 24 dogs suspected of leptospirosis. Diagnostic techniques are based on questionnaires and clinical symptom evaluation, physical examination and biochemical analysis, serum and hematology, and the Microscopic Agglutination Test (MAT) test. The sample criteria were dogs with leukocytosis, thrombocytopenia, azotemia with Blood Urea Nitrogen (BUN) and high keratin. The sample then tested the MAT. Measurement of risk factors in the form of variable questionnaires with laboratory test results using the Chi-square test. Leptospira serovars were identified as bataviae (9 samples), icterohaemorrhagiae (6 samples), tarassovi (4 samples) and javanica (2 samples). The distribution of leptopsira serovars in the study area is quite diverse. Risk factors that increase the incidence of leptospirosis in dogs are the maintenance system (OR 17.50), history of contact with rats (OR 9.625), flood-affected areas (OR 3.50) and drinking water sources (OR 1.643). Floods can be a medium for transmitting leptospira bacteria to dogs. Risk factors such as rearing systems, poor sanitation and a history of contact with rats can increase the incidence of leptospirosis in dogs in areas with high rain intensity. The role of dog owners is needed in preventing the incidence of leptospirosis in dogs.
\end{abstract}

Keywords: Dog; flood; leptospirosis; microscopic aglutination test; serovar

\section{ABSTRAK}

Leptospirosis adalah zoonosis yang telah menjadi masalah serius, terutama di daerah dengan curahan hujan yang tinggi. Leptospirosis berlaku secara besar-besaran selepas hujan lebat atau banjir. Kajian ini bertujuan untuk menganalisis jenis dan taburan serovar bakteria leptospira dan faktor risiko untuk leptospirosis pada anjing pasca banjir. Penyelidikan dilakukan dari Januari hingga Mac 2020 di Rumah Sakit Hewan Ragunan dan klinik bebas di Jakarta, Bekasi, Depok dan Tangerang Selatan. Kajian ini menggunakan kajian keratan rentas sampel serum daripada 24 anjing yang disyaki leptospirosis. Teknik diagnostik didasarkan pada soal selidik dan penilaian gejala klinikal, pemeriksaan fizikal dan analisis biokimia, serum dan hematologi serta ujian mikroskopi penggabungan (MAT). Kriteria sampel adalah anjing dengan leukositosis, trombositopenia, azotemia dengan darah nitrogen urea (BUN) dan keratin tinggi. Sampel kemudian diuji dengan MAT. Pengukuran faktor risiko dalam bentuk soal selidik berubah-ubah dengan hasil ujian makmal menggunakan uji khi kuasa dua. Serovar Leptospira dikenal pasti sebagai bataviae (9 sampel), icterohaemorrhagiae (6 sampel), tarassovi (4 sampel) dan javanica (2 sampel). Taburan serovar leptopsira di kawasan kajian agak pelbagai. Faktor risiko yang meningkatkan kejadian leptospirosis pada anjing adalah sistem pemeliharaan (OR 17.50), sejarah hubungan dengan tikus (OR 9.625), kawasan yang dilanda banjir (OR3 .50) dan sumber air minum (OR 1.643). Banjir boleh menjadi medium penyebaran bakteria leptospira kepada anjing. Faktor risiko seperti sistem pemeliharaan, sanitasi yang buruk dan sejarah sentuhan dengan tikus dapat meningkatkan kejadian leptospirosis pada anjing di kawasan yang mempunyai keamatan hujan tinggi. Peranan pemilik anjing sangat diperlukan dalam mencegah kejadian leptospirosis pada anjing.

Kata kunci: Anjing; banjir; leptospirosis; ujian mikroskopi penggabungan; serovar 


\section{INTRODUCTION}

Leptospirosis is a zoonosis caused by Leptospira bacteria. Leptospira bacteria are included in the Trepanometaceae family, order Spirochaeta. These bacteria are spiral-shaped with tight coils and hook-shaped ends so that the bacteria are very active (Mohammed et al. 2011). Animals that can act as reservoirs include rats, dogs and livestock such as cows, goats, sheep and pigs (Anis et al. 2012; Desvars et al. 2011). Leptospirosis is still a public health problem, especially in tropical and subtropical climates with high rainfall (Bierque et al. 2020). Flood becomes a medium of transmission and can provide an optimal environment for the survival of leptospira bacteria (Haake \& Paul 2015).

The results of the Bierque et al. (2020) study report that leptospira bacteria can survive in environments with a $\mathrm{pH}$ approaching neutral and slum environments such as muddy soil, stagnant water and poor house drainage. Rats are a reservoir capable of transmitting leptospira bacteria for life without showing clinical manifestations or as life carriers (Koizumi et al. 2019). Not all animals infected with Leptospirosis show symptoms of illness (Ellis 2015). Dogs and cattle are natural hosts for certain serovars which usually show no symptoms or are relatively mild after being infected with these serovars, but they can become seriously ill after becoming infected with other serovars (Guernier et al. 2018).

Reports of the incidence of Leptospirosis in dogs in Switzerland showed the main clinical symptoms in the kidney (99.6\%), lung (76.7\%), and liver (26.0\%), as well as hemorrhagic syndrome (18.2\%) which caused the mortality amounted to (43.3\%) (Major et al. 2014). The signs of Leptospirosis in dogs are often nonspecific and may include fever, myalgia, anorexia, vomiting, and diarrhea (Miotto et al. 2018). Specific symptoms such as jaundice, fever, abdominal pain, muscle aches and stiffness, uveitis, dyspnea and coagulopathy also occur but the frequency is low (McCallum et al. 2019). Seven days of bacterial invasion, signs are mild and limited to lethargy and mild hyperemia. Infected dog with severe clinical symptoms at 9 days and worsening for up to 13 days. Other symptoms such as acute renal failure and liver disease are also common in dogs (Brown 1996). Acute Renal Failure (AKI) in dogs, accounting for more than $90 \%$ of reported cases is Leptospirosis. Risk factors that have been associated with Leptospirosis include water exposure, male gender, and sheepdog or working dog in several research studies (Harkin 2012; Ward et al. 2004).

Dogs are one of the animals that are able to transmit leptospira bacteria to humans through urine.
The incidence of Leptospirosis in humans in Indonesia was reported as many as 895 cases during 2018, with a mortality rate of $17.8 \%$ and an annual mortality of $39.2 / 100,000$ population. DKI Jakarta is an endemic area of leptospirosis with high flood intensity (Ministry of Health 2019).

Information on the distribution of leptopsira bacteria serovar and the risk factors affecting dogs is still very limited. In addition, data on leptospira cases in dogs in post-flood urban areas is still limited and has not even become a concern. Based on this, this research is necessary. This study aims to analyze the types and distribution of leptospira bacteria serovars in dogs in Jakarta, Bekasi, Depok and South Tangerang. Post flood 2020 and risk factors affecting the incidence of Leptospirosis in dogs during the study.

\section{MATERIALS AND METHODS}

\section{STUDY AREA}

The research was conducted at Ragunan Animal Hospital, South Jakarta, Indonesia from January 2020 to March 2020.

\section{STUDY DESIGN AND SAMPLES}

The study used a cross-sectional study of 24 samples of dogs suspected of Leptospirosis who were treated at the Jakarta Animal Hospital and independent clinics in Jakarta, Bekasi, Depok and South Tangerang. 21 dogs from flood-affected areas and 3 dogs were not affected by the flood. The samples were then evaluated for clinical symptoms, physical examination and biochemical analysis, serum and hematology, and the MAT test. Dogs showing symptoms of jaundice, hypertemia, gastrointestinal, urogenital and respiratory symptoms are then subjected to a hematology examination with the Hematology Analyzer Rayto RT-7600 machine to determine the number of red blood cells (RBC), white blood cells (RBC) and platelet count (PLT). Biochemical examination using the Photometer Rayto RT 9200 chemistry Analyzer to determine levels of alkaline phosphatase (ALP), alanine aminotransferase (ALT), serum concentration of urea nitrogen in the blood (BUN) and creatinine (CR). The research design refers to the method of Mioto et al. (2018). In general, the criteria for samples with suspected leptospirosis include leukocytosis, thrombocytopenia, azotemia with Blood Urea Nitrogen (BUN) and high keratin. The sample then tested the Microscopic Agglutination Test (MAT). 
Measurement of risk factors in the form of variable questionnaires with laboratory test results using the Chi-square test.

PROCEDURES

BLOOD SAMPLE

The tools used are: $3 \mathrm{~mL}$ syringe, 70\% alcohol, serum separator tube (SST) II contens clot activator and gel 4 $\mathrm{mL}$. The collected serum was stored in a $2 \mathrm{~mL}$ micro tube and a micro tube rack for serological testing. The blood sample is taken from the cephalic vein dogs with suspect Leptospirosis from clinical symptoms after an examination by a veterinarian at a veterinary hospital or independent veterinary practice as much as 3-5 mL. Intake was done using a venoject tube without anticoagulant or serum separator tube (SST) II. Blood was then separated from the serum for leptospirosis by MAT test.

\section{MICROSCOPIC AGGLUTINATION TEST}

MAT method was carried out by filling 96 wells on the microtiter plate with $50 \mu \mathrm{L}$ of serum diluted with Phosphate Buffer Saline (PBS) with a ratio of 1: 25 (100: $2400 \mu \mathrm{L}$ ) and the wells were then filled with the same volume to have a serum and PBS ratio of 1: 50, 1: 100, 1: 400 and 1: 1600. Live Leptospira Antigens from IVETRI (Indonesia Research Centre for Veterinary Sciences) (serovar: ichterohaemorrhagiae, javanica, celledoni, ballum, pyrogenes, cynopeteri, rachmati, australis, pomona, canicola, grippotyphosa, bataviae, hardjo, tarassovi) $0.05 \mathrm{~mL}$ were added, then incubated at two temperatures of $28-30{ }^{\circ} \mathrm{C}$ during $2 \mathrm{~h}$ (Marbawati $\&$ Ismanto 2010). The figure of the results MAT test is viewed under a dark field or phase contrast microscope. The $50 \%$ agglutinated or $50 \%$ unagglutinated Leptospira reaction is the end point of the MAT test reading. Samples with a titer $>100$ shows that the test reacts positively to the serovar used (Marbawati \& Ismanto 2010)

\section{DATA ANALYSIS}

Bivariate analysis was carried out to determine the influence of each risk factor (independent variable) on the incidence of Leptospirosis cases (dependent variable) by using the Chi-square test with confidence level as $95 \%$ on the dependent variable of the serological MAT Test and analyzed using IBM SPSS software 21.0. The independent variable is a type of variable that explains or influences other variables, while the dependent variable is the type of variable that is influenced by the independent variable. The strength of the association can be measured using the RR and or OR in a $2 \times 2$ table (Budiharta \& Suardana 2002).

\section{RESULTS AND DISCUSSION}

RESULT

Distribution of canine leptospirosis after flood as shown in Figure 1.

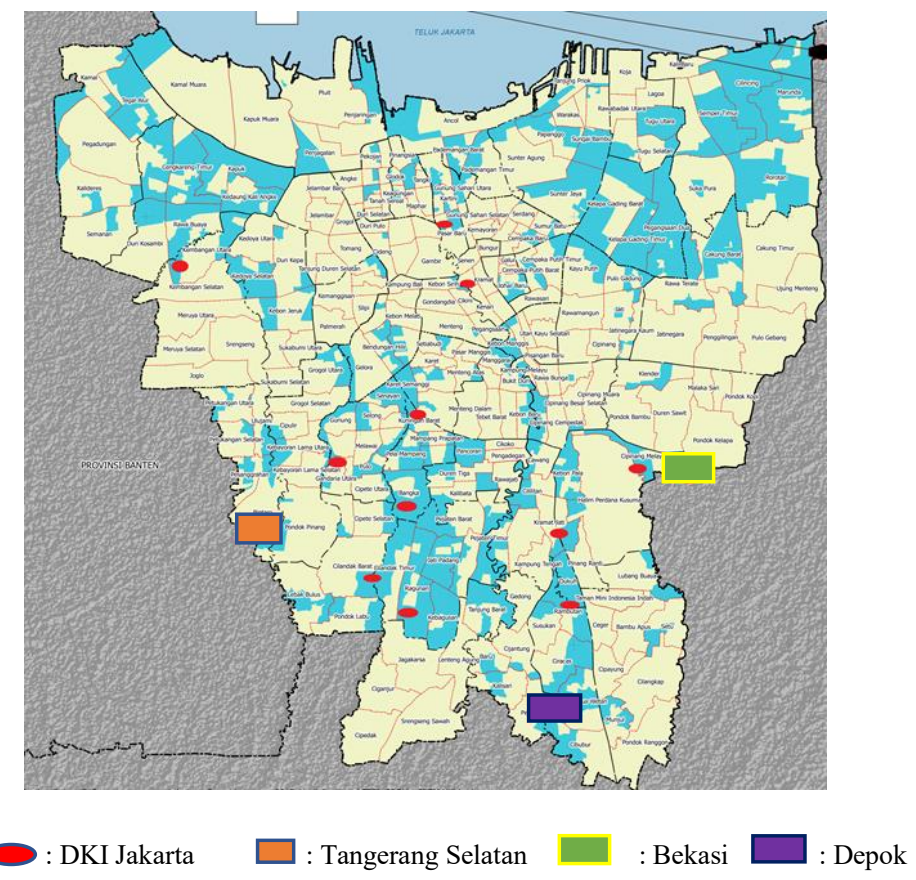

FIGURE 1. Distribution of Canine Leptospirosis as flood-affected January until March 2020 
Based on the result, canine with positive Leptospirosis with MAT test laboratory were distributed in Jakarta 11 district which includes South Jakarta 5 district (Ragunan, Cilandak Barat, Bangka, Kebayoran Lama), West Jakarta 1 district (Kembangan), Center Jakarta 2 (Gunung Sahari, Kebon Sirih), and East Jakarta 3 district (Cipinang, Kampung Melayu, Kramat Jati). Other areas like Depok district (Depok), Bekasi 1 district (Bekasi) and South Tangerang 1 district (Bintaro).

Distribution cases of Leptospirosis after flood from dog serum samples during January until March
2020 are presented in Table 1. Total samples of dogs examined were 24, where after the MAT test, 14 were positively infected with Leptospirosis and 10 were not infected with Leptospirosis. Dog samples from North Jakarta based on the MAT test were not infected with Leptospirosis. The leptospira serovar bacteria found in positive samples consisted of bataviae, icterohaemorrhagiae, javanica, and tarassovi. Serovar bataviae, which is the serovar of leptospira bacteria, is mostly found in dog samples, while the lowest is serovar tarassovi.

TABLE 1. Distribution cases of Leptospirosis after flood from dog serum samples during January until March 2020

\begin{tabular}{|c|c|c|c|c|}
\hline Sample of Origin & Amount sample & $\begin{array}{c}\text { Negative Result } \\
\text { MAT }\end{array}$ & $\begin{array}{c}\text { Positive Result } \\
\text { MAT }\end{array}$ & Serovar \\
\hline South Jakarta & 9 & 4 & 5 & bataviae, tarassovi \\
\hline West Jakarta & 1 & 0 & 1 & icterohaemorrhagiae, javanica \\
\hline North Jakarta & 3 & 3 & 0 & - \\
\hline Center Jakarta & 2 & 0 & 2 & bataviae, icterohaemorrhagiae \\
\hline East Jakarta & 3 & 0 & 3 & $\begin{array}{c}\text { bataviae, icterohaemorrhagiae, } \\
\text { javanica, tarassovi }\end{array}$ \\
\hline South Tangerang & 2 & 1 & 1 & bataviae \\
\hline Bekasi & 1 & 0 & 1 & bataviae \\
\hline Depok & 3 & 2 & 1 & icterohaemorrhagiae \\
\hline
\end{tabular}

Serovars used in the MAT test are: icterohamorragie, javanica, celledoni, canicola, ballum, pyrogenes, cynopteri, rachmati, australis, pomona, grippotyphosa, hardjo batavia and tarassovii

Table 2 shows the MAT test titers contained in each infecting serovar, the titers in the MAT test vary, the results are said to be positive if the titer shows a positive reaction to the serovar at a 1: 100 reactions. This study resulted in varying titers, namely 1: 100; 1: 400 and the highest titer 1: 1600 for serovar bataviae in the Bekasi area.
The data in Table 3 shows that $75 \%$ of dogs suffering from Leptospirosis are working dogs, or dogs used for hunting or guarding houses and yards or gardens, 25\% are pet dogs. Dogs with male sex by $75 \%$, and female dogs by $25 \%$. The mean age of dogs affected by Leptospirosis $(91.7 \%)$ was more than one-year-old. Puppy dogs or less than a year only about $8.3 \%$ affected by Leptospirosis. 
TABLE 2. Titer MAT results from dog serum samples during January until March 2020

\begin{tabular}{|c|c|c|c|c|c|}
\hline Sample of origin & Amount sample & Bataviae & Icterohaemorrhagiae, & Javanica & Tarassovi \\
\hline \multirow[t]{5}{*}{ South Jakarta } & 5 & $1: 100$ & - & - & - \\
\hline & & $1: 400$ & - & - & $1: 100$ \\
\hline & & $1: 100$ & - & - & - \\
\hline & & $1: 400$ & - & - & - \\
\hline & & $1: 400$ & - & - & $1: 400$ \\
\hline West Jakarta & 1 & - & $1: 100$ & $1: 100$ & - \\
\hline North Jakarta & 0 & - & - & - & - \\
\hline \multirow[t]{2}{*}{ Center Jakarta } & 2 & $1: 400$ & $1: 100$ & - & - \\
\hline & & - & $1: 100$ & - & - \\
\hline \multirow[t]{3}{*}{ East Jakarta } & 3 & $1: 400$ & - & $1: 400$ & - \\
\hline & & - & $1: 100$ & - & $1: 100$ \\
\hline & & - & $1: 100$ & - & $1: 400$ \\
\hline South Tangerang & 1 & $1: 100$ & - & - & - \\
\hline Bekasi & 1 & $1: 1600$ & - & - & - \\
\hline Depok & 1 & - & $1: 100$ & - & - \\
\hline
\end{tabular}

TABLE 3. Frequency distribution of sample data during the study through a questionnaire

\begin{tabular}{|c|c|c|c|}
\hline Category & Description & Amount & $(\%)$ \\
\hline \multirow{2}{*}{ Type of dog } & Pet dog & 6 & 25.00 \\
\hline & Working dog & 18 & 75.00 \\
\hline \multirow[t]{2}{*}{ Sex } & Male & 18 & 25.00 \\
\hline & Female & 6 & 75.00 \\
\hline \multirow[t]{2}{*}{ Age } & Adult & 22 & 91.00 \\
\hline & Puppy & 2 & 8.30 \\
\hline \multirow[t]{2}{*}{ History of Vaccination } & Yes & 16 & 66.67 \\
\hline & No & 8 & 33.33 \\
\hline \multirow[t]{2}{*}{ Maintenance system } & House hold & 6 & 25.00 \\
\hline & No house hold & 18 & 75.00 \\
\hline \multirow[t]{2}{*}{ History contact of rat } & No & 11 & 45.80 \\
\hline & Yes & 13 & 54.20 \\
\hline \multirow[t]{2}{*}{ Flood affected area } & No & 3 & 12.50 \\
\hline & Yes & 21 & 87.50 \\
\hline \multirow[t]{3}{*}{ Categorical of flood } & (High) & 4 & 16.70 \\
\hline & (Medium) & 14 & 70.80 \\
\hline & No flood (Low) & 3 & 12.50 \\
\hline \multirow[t]{2}{*}{ Source of drinking water } & Boiled water & 1 & 4.20 \\
\hline & Raw water & 23 & 95.80 \\
\hline \multirow[t]{2}{*}{ Recovery } & Life & 7 & 29.20 \\
\hline & Death & 17 & 70.80 \\
\hline
\end{tabular}

Total sample of the study was 24 dogs 
The risk factors for canine Leptospirosis after flooding are presented in Table 4 . There is a significant relationship $(\mathrm{P}<0.05)$ where the strength of association (OR) is high for canine Leptospirosis in this study: Maintenance system, history of contact with rats, floodaffected areas, flood category and recovery phase. The risk factors that increased the incidence of Leptospirosis in dogs were the maintenance system (OR 17.50) with
$(\mathrm{P}<0.001)$, history of contact with mice (OR 9.625) with $(\mathrm{P}<0.05)$, flood-affected areas (OR 3.50) with $(\mathrm{P}<0.05)$, drinking water sources (OR 1.643) with $(\mathrm{P}<0.05)$, and dog recovery status (OR 2.125) with $(\mathrm{P}<0.05)$. Dogs that were not exposed to flooding decreased the incidence of Leptospirosis (OR 0.286) by $(\mathrm{P}<0.05)$. Flood risk factors and the presence of reservoirs influenced the acute incidence of Leptospirosis in dogs from this study.

TABLE 4. Bivariate analysis of risk factor

\begin{tabular}{lccc}
\hline Category & Crude OR & CI 95\% & P-value \\
\hline Type of dog (working dog/pet dog) & 5.20 & $0.714-37.895$ & 0.088 \\
Sex (Male/female) & 0.25 & $0.240-2.594$ & 0.224 \\
Age (adult/puppy) & 0.591 & $0.417-0.837$ & 0.253 \\
Vaksinasi (Yes/No) & 1.00 & $0.173-5.772$ & 1.000 \\
Maintenance system (Household/ & 17.50 & $1.560-196.319$ & $0.007^{* * *}$ \\
No) & 9.625 & $1.378-67.246$ & $0.035^{* *}$ \\
History contact of rat (Yes/No) & 3.50 & $1.780-6.883$ & $0.021^{* *}$ \\
Flood affected area (Yes/No) & 0.286 & $0.145-0.562$ & $0.017^{* *}$ \\
Categorical flood (Yes/No) & 1.643 & $1.184-2.280$ & 0.429 \\
Source of drinking water (raw water/ & & & $0.015^{* *}$ \\
boiled water) & & $1.283-3.518$ & \\
Recovery (Infausta/ fausta) & 2.125 & & \\
\hline
\end{tabular}

Total sample of the study was 24 dogs; $95 \% \mathrm{CI}$; *** very significant $(\mathrm{P}<0.01) * *$ more significant $(\mathrm{P}<0.05)$.

Case fatality rate (CRF) cases of Leptospirosis were calculated based on dogs that were positive confirmed by the gold standard MAT test (Table 5). The CFR of Leptospirosis cases during the 3-month study period showed a rate of $40.47 \%$.

TABLE 5. Case fatality rate for Leptospirosis cases from January to March 2020

\begin{tabular}{lcccc}
\hline Time & MAT $(+)$ & Monthly Mortality & CFR (\%) & Average (\%) \\
\hline January & 7 & 5 & $5 / 7(71,42)$ & 40,47 \\
February & 4 & 2 & $2 / 4(50,00)$ & \\
March & 3 & 0 & $0 / 3(0,00)$ & \\
\hline
\end{tabular}




\section{DISCUSSION}

The Leptospirosis can be spread due to flood water to several areas where rat urine containing leptospira contaminates the stagnant water (Naing et al. 2019; Sykes et al. 2011). Leptospira in Indonesia is mainly caused by mice that release the bacteria into the environment through urine, brown mice (Rattus norvegicus) and garden rats (Rattus exulans) are the source of transmission to animals and humans (Gasem et al. 2020; Ministry of Health 2017). Leptospirosis is still a threat to public health in Indonesia because it is related to the presence of risk factors, namely the high population of rodents as an environmental reservoir, poor environmental sanitation and frequent flooding in 2020, which can cause acute leptospirosis in dogs.

The incidence of Leptospirosis in dogs can be influenced by the inherent conditions of the individual dog (such as the dog's age, gender, purpose of keeping the $\operatorname{dog}$ ) and daily habits such as frequent hunting of mice. External factors such as flooding can be a medium for transmission of leptospira bacteria. Pathogenic Leptospirosis has the ability to form biofilms in vitro and survive in biofilms under natural conditions (Garba et al. 2018; Polo et al. 2019). Leptospira can also interact with other soil community members such as Amoeba, which is one of the main colonies in drinking water as a reservoir for potentially pathogenic bacteria (Boey et al. 2019). According to Collantes et al. (2016) and Levett (2001), clinical symptoms of dogs infected with Leptospirosis include azotemia, myalgia, vomiting, anorexia, fever, hyperemia in the area of the molle pallatum or intraorbital, jaundice, production of cytokines by monocytes, macrophages, and other cells that have an impact on vascular permeability disorders, pressure drops blood, anorexia, and unstable body temperature.

MAT is a serological test that has high sensitivity and specificity for detecting serovars (Miotto et al. 2018; Reagan \& Sykes 2019). Serovar bataviae dominates Leptospirosis-positive dogs in several areas in this study, namely South Jakarta, Central Jakarta, East Jakarta, South Tangerang, Depok and Bekasi. Exposure can occur through direct contact with infected animals or through indirect contact through soil or water contaminated with urine from infected animals (Haake \& Paul 2015). Serovars bataviae and icterohaemorrhagiae are found in many cases of leptospirosis in humans. Serovars tarassovi are commonly found in cattle, but in this study 4 dogs reacted positively to this serovar. Serovars tarassovi are usually found in livestock, especially pigs, because they are carriers of serovars tarassovi and act as reproductive disorders in pigs (Ministry of Agriculture 2012).

The antibody titer against MAT varies widely which is thought to be influenced by the different immune response of each individual dog. A total of 14 dogs positive for MAT showed agglutination antibodies against 9 dogs infected with serovar bataviae, serovar icterohaemorrhagiae infected 6 dogs, serovar javanica infected 2 dogs and serovar tarassovi infected 4 dogs. Changes in serovar prevalence are thought to be related to two main factors that greatly influence the epizoology of Leptospira serovars (Harkin 2012). Vaccination can prevent Leptospirosis in dogs. Serovars icterohaemorrhagiae and canicola were the most common serovars found in the field. The involvement of additional serovars such as serovar bataviae and tarassovi needs to be an important concern. Dogs that have been vaccinated can contract leptospirosis due to differences in the serovars that infect, commercial vaccines in the field only protect against icterohaemorrhagiae and canicola serovars, so it is necessary to add a serovar vaccine from other leptospira bacteria. According to Altheimer et al. (2020), the use of vaccines against leprospira cases in dogs needs to be done because the results of the study indicate the potential risk of zoonoses that should not be underestimated with a high infection rate.

The average case fatality rate within 3 months of the study was very high, namely $40.47 \%$ (Table 5). The calculation of CFR is based on dogs that have been confirmed by the MAT test. The highest Leptospirosis cases and mortality occurred in January 2020, namely $71.42 \%$. The conditions of the research area in January were high rainfall and floods. This is thought to be a factor in the high cases of Leptospirosis in the study area. In addition, veterinarians still lack knowledge when diagnosing early cases of Leptospirosis. Dogs infected with Leptospirosis sometimes do not show specific symptoms such as jaundice and conjunctival suffusion, but show non-specific symptoms such as general weakness and gastrointestinal symptoms. In addition, the obstacle of MAT testing is that it takes a long time and laboratory facilities are quite expensive. Historical information such as the proximity of the animal to the rat reservoir and originating from the flooded area is expected to support the diagnosis of Leptospirosis cases in dogs.

Decreased cases of death were caused by several factors such as clinical accuracy and socialization 
programs to veterinary hospitals and veterinary clinics regarding Leptospirosis cases to veterinarians so that case handling was carried out appropriately by selecting the appropriate treatment. Therapeutic antibiotics and support were provided throughout the study. Therefore, the choice of therapeutic treatment must be made appropriately in the administration of antibiotics. Ampicillin $500 \mathrm{mg}$ every $6 \mathrm{~h}$ or doxycycline $100 \mathrm{mg}$ twice daily can be used to treat mild Leptospirosis, whereas for severe cases Penicillin G 1.5 MU can be used intravenously every 6 h (Edwards 2004).

\section{Conclusion}

Leptospira serovar bataviae, icterohaemorrhagiae, tarassovi, and javanica were found in post-flood dogs by MAT testing. The risk factors that increased the incidence of Leptospirosis in dogs were maintenance system (OR 17.50), history of contact with rats (OR 9.625), floodaffected areas (OR 3.50), drinking water sources (OR 1.643 ) and status of dog recovery (OR 2.125). Dogs that were not affected by flooding decreased the incidence of Leptospirosis cases (OR 0.286). The factors of flood risk and the presence of a reservoir influenced the acute incidence of Leptospirosis in dogs from this study. Post flood leptospirosis cases in several areas need to be an important concern because they have a high mortality. Vaccination precautions in dogs and addition of local isolate serovar vaccines are also recommended.

\section{ACKNOWLEDGEMENTS}

We are also grateful to the Agency for Agricultural Extension and Human Resources Development (AAEHRD) Ministry of Agriculture of the Republic of Indonesia that has provided scholarship and research funds.

\section{REFERENCES}

Altheimer, K., Jongwattanapisan, P., Luengyosluechakul, S., Pusoonthornthum, R., Prapasarakul, N., Kurilung, A., Broens, E.M., Wagenaar, J.A., Goris, M.G.A., Ahmed, A.A., Pantchev, N., Reese, S. \& Hartmann, K. 2020. Leptospira infection and shedding in dogs in Thailand. BMC Veterinary Research 16(1): 89.

Anis, K., Andi, Y. \& Ika, N. 2012. Optimizing real-time PCR method to detect Leptospira spp. in human blood and urine specimens. Med J. Indones 21(1): 13-17.

Bierque, E., Thibeaux, R., Girault, D., Soupé-Gilbert, M.E. \& Goarant, C. 2020. A systematic review of leptospira in water and soil environments. PLoS ONE 15(1): e0227055.
Boey, K., Shiokawa, K. \& Rajeev, S. 2019. Leptospira infection in rats: A literature review of global prevalence and distribution. PLoS Neglected Tropical Diseases 13(8): e0007499.

Brown, C.A., Roberts, A.W., Miller, M.A., Davis, D.A., Brown, S.A., Bolin, C.A., Jarecki-Black, J., Greene, C.E. \& MillerLiebl, D. 1996. Leptospira interrogans serovar grippotyphosa infection in dogs. Journal of The American Veterinary Medical Association 209(7): 1265-1267.

Budiharta, S. \& Suardana, I.W. 2002. Epidemiologi dan Ekonomi Veteriner. Bali (ID): Udayana University Press.

Collantes, T.M., David, J.M., Vergara, E.J., Armea, S.R. \& Flores, M.L. 2016. Detection of pathogenic leptospirosis and analysis of factors and clinical signs associated with canine leptospirosis. Philippine Journal of Veterinary and Animal Sciences 42(1): 41-48.

Desvars, A., Cardinale, E. \& Michault, A. 2011. Animal leptospirosis in small tropical areas. Epidemiology and Infection 139(2): 167-188.

Edwards, C.N. \& Levett, P.N. 2004. Prevention and treatment of leptospirosis. Expert Review of Anti-Infective Therapy 2(2): 293-298.

Ellis, W.A. 2015. Animal leptospirosis. Current Topics in Microbiology and Immunology 387: 99-137.

Garba, B., Bahaman, A.R., Bejo, S.K., Zakaria, Z., Mutalib, A.R. \& Bande, F. 2018. Major epidemiological factors associated with leptospirosis in Malaysia. Acta Tropica 178: 242-247.

Gasem, M.H., Hadi, U., Alisjahbana, B., Tjitra, E., Hapsari, M., Lestari, E.S., Aman, A.T., Lokida, D., Salim, G., Kosasih, H., Merati, K., Laras, K., Arif, M., Lukman, N., Sudarmono, P., Lisdawati, V., Lau, C.Y., Neal, A. \& Karyana, M. 2020. Leptospirosis in Indonesia: Diagnostic challenges associated with atypical clinical manifestations and limited laboratory capacity. BMC Infectious Diseases 20(1): 179-190.

Guernier, V., Goarant, C., Benschop, J. \& Lau, C.L. 2018. A systematic review of human and animal leptospirosis in the Pacific Islands reveals pathogen and reservoir diversity. PLoS Neglected Tropical Diseases 12(5): e0006503.

Haake, D.A. \& Levett, P.N. 2015. Leptospirosis in humans. Current Topics in Microbiology and Immunology 387: 65-97.

Harkin, K.R. 2012. Canine leptospirosis: A perpective on recent trends. Today's Veterinary Practice 2(4): 27-33.

Marbawati, D. \& Ismanto, H. 2010. Pemeriksaan leptospirosis secara laboratoris. Balaba 6(1): 1-31.

Koizumi, N., Miura, K., Sanai, Y., Takemura, T., Ung, T.T.H., Le, T.T., Hirayama, K., Hasebe, F., Nguyen, H.L.K., Hoang, P.V.M., Nguyen, C.N., Khong, T.M., Le, M.T.Q., Hoang, H.T.T. \& Ohnishi, M. 2019. Molecular epidemiology of Leptospira interrogans in Rattus norvegicus in Hanoi, Vietnam. Acta Tropica 194: 204-208.

Levett, P.N. 2001. Leptospirosis. Clinical Microbiology Reviews 14(2): 296-326. 
Major, A., Schweighauser, A. \& Francey, T. 2014. Increasing incidence of canine leptospirosis in Switzerland. International Journal of Environmental Research and Public Health 11(7): 7242-7260.

McCallum, K.E., Constantino-Casas, F., Cullen, J.M., Warland, J.H., Swales, H., Linghley, N., Kortum, A.J., Sterritt, A.J., Cogan, T. \& Watson, P.J. 2019. Hepatic leptospiral infections in dogs without obvious renal involvement. Journal of Veterinary Internal Medicine 33(1): 141-150.

Ministry of Health. 2017. Petunjuk Teknis Pengendalian Leptospirosis, Cetakan Ke-3. Jakarta (ID): Ministry of Health.

Ministry of Agriculture. 2012. Manual Penyakit Hewan Mamalia. Jakarta (ID): Ministry of Agriculture.

Ministry of Health. 2019. Profil Kesehatan Indonesia 2018. Jakarta (ID): Ministry of Health.

Miotto, B.A., Guilloux, A.G.A., Tozzi, B.F., Moreno, L.Z., Da Hora, A.S., Dias, R.A., Heinemann, M.B., Moreno, A.M., de Souza Filho, A.F., Lilenbaum, W. \& Hagiwara, M.K. 2018. Prospective study of canine leptospirosis in shelter and stray dog populations: Identification of chronic carriers and different leptospira species infecting dogs. PLOS ONE 13(7): e0200384.

Miotto, B.A., Tozzi, B.F., Penteado, M.S., Guilloux, A.G.A., Moreno, L.Z., Heinemann, M.B., Moreno, A.M., Lilenbaum, W. \& Hagiwara, M.K. 2018. Diagnosis of acute canine leptospirosis using multiple laboratory tests and characterization of the isolated strains. BMC Veterinary Research 14(222): 1-9.

Mohammed, H., Nozha, C., Hakim, K. \& Abdelaziz, F. 2011. Leptospira: Morphology, classification and pathogenesis. Journal of Bacteriology and Parasitology 2(6): 6-9.

Naing, C., Reid, S.A., Aye, S.N., Htet, N.H. \& Ambu, S. 2019. Risk factors for human leptospirosis following flooding: A meta-analysis of observational studies. PLoS ONE 14(5): e0217643.
Polo, N., Machado, G., Rodrigues, R., Hamrick, P.N., MunozZanzi, C., Pereira, M.M., Bercini, M., Timm, L.N. \& Schneider, M.C. 2019. A one health approach to investigating leptospira serogroups and their spatial distributions among humans and animals in Rio Grande do Sul, Brazil. Tropical Medicine Infectious Disease 4(1): 42-60.

Reagan, K.L. \& Sykes, J.E. 2019. Diagnosis of canine leptospirosis. Veterinary Clinics of North America: Small Animal Practice 49(4): 719-731.

Sykes, J.E., Hartmann, K., Lunn, K.F., Moore, G.E., Stoddard, R.A. \& Goldstein, R.E. 2011. 2010 ACVIM small animal consensus statement on leptospirosis: Diagnosis, epidemiology, treatment, and prevention. Journal Veteriner International Medicine 25(1): 1-13.

Ward, M.P., Guptill, L.F., Prahl, A. \& Wu, C.C. 2004. Serovarspecific prevalence and risk factors for leptospirosis among dogs: 90 cases (1997-2002). Journal of the American Veterinary Medical Association 224(12): 1958-1963.

Ambar Retnowati

Veterinary Public Health Study Program

IPB University

Indonesia

Agustin Indrawati*, Upik Kesumawati Hadi \& Safika Department of Animal Diseases and Veterinary Public Health IPB University

Indonesia

Susan M Noor

Veterinary Research Center

Ministry of Agriculture

Indonesia

*Corresponding author; email: indraseta@apps.ipb.ac.id

Received: 10 November 2020

Accepted: 19 April 2021 